\title{
Fit the operation to the patient, not the patient to the operation
}

\author{
Joseph F. Sabik III, MD
}

\footnotetext{
From the Department of Thoracic and Cardiovascular Surgery, Heart and Vascular Institute, Cleveland Clinic, Cleveland, Ohio.

Supported by the Department of Thoracic and Cardiovascular Surgery, Cleveland Clinic, Cleveland, Ohio. Disclosers: Author has nothing to disclose with regard to commercial support.

Received for publication Sept 3, 2015; accepted for publication Sept 3, 2015; available ahead of print Oct 3, 2015. Address for reprints: Joseph F. Sabik III, MD, Department of Thoracic and Cardiovascular Surgery, Cleveland Clinic, 9500 Euclid Ave, Desk J4-1, Cleveland, OH 44195 () (E-mail: sabikj@ccf.org). J Thorac Cardiovasc Surg 2015;150:1393-5 $0022-5223 / \$ 36.00$

Copyright (C) 2015 Published by Elsevier Inc. on behalf of The American Association for Thoracic Surgery http://dx.doi.org/10.1016/j.jtcvs.2015.09.010
}

"Off-Pump Revascularization Is Best." "All-Arterial Grafting Should Be Our Preferred Grafting Strategy." These are common titles for presentations at our national meeting. Astute surgeons, however, ask themselves, "Best and preferred for whom?" Knowing what coronary artery bypass grafting (CABG) technique to perform for what patient is central to doing what is best for that patient. This requires answering 3 questions: What must be accomplished and avoided? What are the strengths and weaknesses of different $\mathrm{CABG}$ techniques? Does the patient have characteristics or comorbidities that make a particular procedure more likely to be successful?

\section{WHAT MUST BE ACCOMPLISHED AND AVOIDED?}

Goals for $\mathrm{CABG}$ are to prolong life and to relieve ischemia. Any CABG operation must accomplish these goals. For some patients, however, it may be equally important to choose a revascularization technique that avoids or minimizes complications associated with CABG. For example, an elderly patient at high risk for stroke will benefit more from a technique that minimizes that risk, even if that technique carries a higher risk of less effective revascularization. A young patient at low risk for stroke will benefit more from a strategy that provides complete revascularization and better graft patency than from one that minimizes stroke risk. Such individualization accomplishes the desired outcome while avoiding negative consequences or complications.

\section{WHAT ARE THE STRENGTHS AND WEAKNESSES OF DIFFERENT CABG TECHNIQUES? Off- Versus On-Pump CABG}

Publications on the strengths and weaknesses of off- versus on-pump CABG are legion. Although still controversial, randomized and observational studies of tens of thousands of patients demonstrate that off-pump CABG lowers in-hospital morbidity, but at the cost of fewer bypass grafts, more incomplete revascularization, more reinterventions for recurrent ischemia, and higher 1-year mortality. ${ }^{1-14}$ Choosing whether to perform on- or off-

\section{Graft Choice}

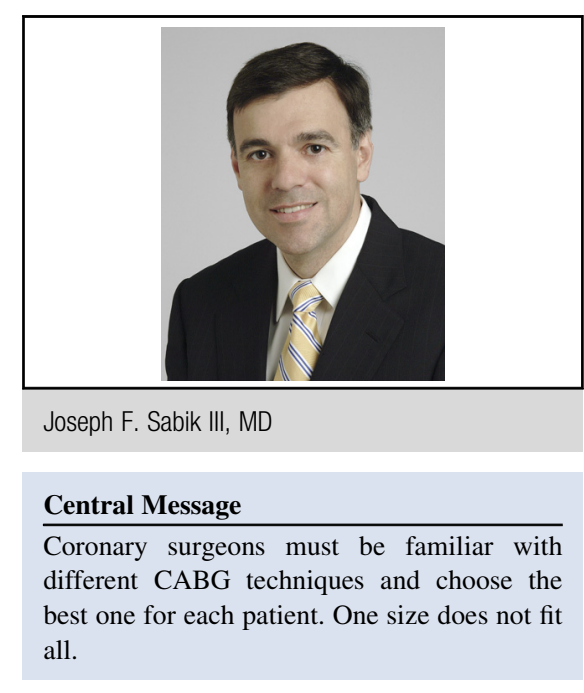

See Articles page 1428 and page 1120 in the November issue.

See Editorial Commentary page 1438.

pump CABG requires surgeons to understand the specifics of their patients and which technique will most likely provide the desired outcome. For example, a young patient at low risk for stroke with extensive coronary artery disease that will be difficult to revascularize is likely best served by on-pump CABG, whereas an elderly patient with ascending aortic atherosclerosis and 2-system coronary artery disease not involving the lateral wall may benefit more from off-pump, no-aortic-touch CABG.

Long-term results of CABG are directly related to graft patency. Recognition of the better patency of internal thoracic artery (ITA) relative to saphenous vein (SV) grafts led surgeons in the late 1970s and early 1980s to adopt left ITA grafting of the left anterior descending coronary artery. This strategy proved to prolong survival and decrease recurrent ischemia. ${ }^{15}$ Soon thereafter, bilateral ITA grafting and other arterial grafts-radial, gastroepiploic, and inferior epigastric-were recommended to improve long-term outcomes of CABG. ${ }^{16-18}$ Although use of the left ITA to graft the left anterior descending coronary artery has become standard of care, the use of other arterial grafts to bypass other coronary arteries has not. This is likely because of the increased complexity and possible morbidity associated with multiple arterial grafting. 
In choosing the best conduit to bypass a stenosed coronary artery, surgeons should weigh the long-term patency of that conduit against the increased complexity and morbidity associated with that choice. Generally, arterial grafts have better patency than vein grafts. The most important factor influencing arterial graft patency is native coronary artery competitive flow. ${ }^{17,19,20}$ This is not, however, as great a deterrent as was once believed. For the left anterior descending coronary artery, diagonal arteries, circumflex coronary arteries, and distal branches of the right coronary artery, ITA grafts have better patency than SV grafts for all degrees of clinically important stenosis. ${ }^{21} \mathrm{SV}$ grafts have better patency than ITA grafts when used to bypass main right coronary arteries with moderate stenosis. ${ }^{21}$ Radial and gastroepiploic arteries, although more susceptible to competitive flow than ITA grafts, have excellent patency when used to bypass arteries with severe stenosis. ${ }^{17,20}$ Understanding patency data is critical in deciding when and when not to use an arterial graft, and if so, which one. Morbidity associated with additional arterial grafts is due to harvesting-site complications, such as hematoma and infection, and sternal wound infection in bilateral ITA grafting.

As expected, better long-term patency of arterial grafts results in better patient outcomes, such as increased survival and decreased recurrent ischemia with bilateral ITA grafting. ${ }^{16}$ So what about adding a third or fourth arterial graft? ${ }^{22}$ Will this further improve outcomes? The answer depends on the patient. Young patients who could outlive their SV grafts may benefit from longer-lasting arterial grafts. During my career, I have treated a few patients who have patent bilateral ITA grafts, but recurrent angina from failed SV grafts. They would likely have benefited from additional arterial grafts. The same extensive arterial revascularization strategy is unnecessary for elderly patients with multiple comorbidities and decreased left ventricular function.

\section{DOES THE PATIENT HAVE CHARACTERISTICS OR COMORBIDITIES THAT MAKE A PARTICULAR PROCEDURE MORE LIKELY TO BE SUCCESSFUL?}

Understanding the patient's characteristics and how these influence success or failure of a CABG technique is crucial in choosing the best revascularization strategy. Ideally, an algorithm would exist in which all important patient characteristics could be entered, and out would come the best procedure for that patient. Unfortunately, such an algorithm is unlikely in the near future, and surgeons will continue to rely on "surgical judgment." Although instincts gained through experience are beneficial, much has been learned about when CABG is best performed on or off pump and when multiple arterial grafts are beneficial.
Off-pump surgery appears to benefit patients at high risk for CABG. In a report from Emory, patients undergoing CABG with a Society of Thoracic Surgeons predicted risk of mortality greater than 3 had lower in-hospital mortality if their operation was performed off pump. ${ }^{23}$ A study from Cleveland Clinic demonstrated that elderly patients and patients with multiple atherosclerotic comorbidities were at greater risk for stroke, and that performing CABG off pump attenuated this risk. ${ }^{24}$

Most patients benefit from multiple arterial grafts. Individual characteristics have been identified that attenuate their benefit, however, and patients with these characteristics receive little or no benefit, and possibly a decrement. An observational study of more than 10,000 patients from Cleveland Clinic demonstrated that all but $2.8 \%$ undergoing CABG derived a survival benefit from bilateral ITA grafting. ${ }^{16,25}$ Patients with poor left ventricular function, those with multiple noncardiac comorbidities, and the elderly derived less (but still some) benefit. A more recent study of nearly 12,000 patients from the same institution demonstrated that patients with diabetes similarly obtained a survival benefit from bilateral ITA grafting; however, they had a higher risk of sternal wound infection. Risk factors included medically treated diabetes, peripheral vascular disease, female sex, and larger body mass index. A reassuring finding was that even patients who had sternal wound infections develop derived a survival benefit from bilateral ITA grafting.

\section{CONCLUSIONS}

Articles and presentations comparing CABG techniques-including our own group's work-routinely suggest that one is better than the other. These conclusions, however, are unlikely to be true for all patients. It is important to choose the procedure that is best for the individual patient by first determining what needs to be accomplished and avoided, understanding different techniques' strengths and weaknesses, and being aware of patient characteristics that make a particular procedure more likely to be successful. CABG can be performed in many ways-on pump, off pump, with the no-aortic-touch technique, and with multiple arterial grafting, to name just a few. The task for the coronary surgeon is to be familiar with the different techniques and use them as best for an individual patient. One size does not fit all.

\footnotetext{
References

1. Sabik JF, Gillinov AM, Blackstone EH, Vacha C, Houghtaling PL, Navia J, et al. Does off-pump coronary surgery reduce morbidity and mortality? J Thorac Cardiovasc Surg. 2002;124:698-707.

2. Houlind K, Fenger-Grøn M, Holme SJ, Kjeldsen BJ, Madsen SN, Rasmussen BS, et al. Graft patency after off-pump coronary artery bypass surgery is inferior even with identical heparinization protocols: results from the Danish On-pump Versus Off-pump Randomization Study (DOORS); DOORS Study Group. J Thorac Cardiovasc Surg. 2014;148:1812-9.e2.
} 
3. Takagi H, Umemoto T. All-Literature Investigation of Cardiovascular Evidence (ALICE) Group. Worse long-term survival after off-pump than on-pump coronary artery bypass grafting. J Thorac Cardiovasc Surg. 2014;148:1820-9.

4. Contini M, Iacò A, Iovino T, Teodori G, Di Giammarco G, Mazzei V, et al. Current results in off pump surgery. Eur J Cardiothorac Surg. 1999;16(Suppl 1): S69-72.

5. Bull DA, Neumayer LA, Stringham JC, Meldrum P, Affleck DG, Karwande SV. Coronary artery bypass grafting with cardiopulmonary bypass versus off-pump cardiopulmonary bypass grafting: does eliminating the pump reduce morbidity and cost? Ann Thorac Surg. 2001;71:170-3; discussion 173-5.

6. Kshettry VR, Flavin TF, Emery RW, Nicoloff DM, Arom KV, Petersen RJ. Does multivessel, off-pump coronary artery bypass reduce postoperative morbidity? Ann Thorac Surg. 2000;69:1725-30; discussion 1730-1.

7. Czerny M, Baumer H, Kilo J, Zuckermann A, Grubhofer G, Chevtchik O, et al. Complete revascularization in coronary artery bypass grafting with and without cardiopulmonary bypass. Ann Thorac Surg. 2001;71:165-9.

8. Arom KV, Flavin TF, Emery RW, Kshettry VR, Janey PA, Petersen RJ. Safety and efficacy of off-pump coronary artery bypass grafting. Ann Thorac Surg. 2000;69:704-10.

9. Lim E, Drain A, Davies W, Edmonds L, Rosengard BR. A systematic review of randomized trials comparing revascularization rate and graft patency of offpump and conventional coronary surgery. J Thorac Cardiovasc Surg. 2006; 132:1409-13.

10. Racz MJ, Hannan EL, Isom OW, Subramanian VA, Jones RH, Gold JP, et al. A comparison of short- and long-term outcomes after off-pump and on-pump coronary artery bypass graft surgery with sternotomy. J Am Coll Cardiol. 2004;43: 557-64.

11. Shroyer AL, Grover FL, Hattler B, Collins JF, McDonald GO, Kozora E, et al; Veterans Affairs Randomized On/Off Bypass (ROOBY) Study Group. Onpump versus off-pump coronary-artery bypass surgery. N Engl J Med. 2009; 361:1827-37.

12. Lamy A, Devereaux PJ, Prabhakaran D, Taggart DP, Hu S, Paolasso E, et al; CORONARY Investigators. Off-pump or on-pump coronary-artery bypass grafting at 30 days. $N$ Engl J Med. 2012;366:1489-97.

13. Diegeler A, Börgermann J, Kappert U, Breuer M, Böning A, Ursulescu A, et al; GOPCABE Study Group. Off-pump versus on-pump coronary-artery bypass grafting in elderly patients. N Engl J Med. 2013;368:1189-98.

14. Cheng DC, Bainbridge D, Martin JE, Novick RJ, Evidence-Based Perioperative Clinical Outcomes Research Group. Does off-pump coronary artery bypass reduce mortality, morbidity, and resource utilization when compared with conventional coronary artery bypass? A meta-analysis of randomized trials. Anesthesiology. 2005;102:188-203

15. Loop FD, Lytle BW, Cosgrove DM, Stewart RW, Goormastic M, Williams GW, et al. Influence of the internal-mammary-artery graft on 10-year survival and other cardiac events. N Engl J Med. 1986;314:1-6.

16. Lytle BW, Blackstone EH, Sabik JF, Houghtaling P, Loop FD Cosgrove DM. The effect of bilateral internal thoracic artery grafting on survival during 20 postoperative years. Ann Thorac Surg. 2004;78:2005-14; discussion 2012-4.

17. Possati G, Gaudino M, Alessandrini F, Luciani N, Glieca F, Trani C, et al Midterm clinical and angiographic results of radial artery grafts used for myocardial revascularization. J Thorac Cardiovasc Surg. 1998;116:1015-21.

18. Suma H, Isomura T, Horii T, Sato T. Late angiographic result of using the right gastroepiploic artery as a graft. J Thorac Cardiovasc Surg. 2000;120:496-8.

19. Sabik JF III, Lytle BW, Blackstone EH, Khan M, Houghtaling PL, Cosgrove DM. Does competitive flow reduce internal thoracic artery graft patency? Ann Thorac Surg. 2003;76:1490-6; discussion 7.

20. Glineur D, D'hoore W, El Khoury G, Sondji S, Kalscheuer G, Funken JC, et al. Angiographic predictors of 6-month patency of bypass grafts implanted to the right coronary artery a prospective randomized comparison of gastroepiploic artery and saphenous vein grafts. J Am Coll Cardiol. 2008;51:120-5.

21. Sabik JF III, Lytle BW, Blackstone EH, Houghtaling PL, Cosgrove DM. Comparison of saphenous vein and internal thoracic artery graft patency by coronary system. Ann Thorac Surg. 2005;79:544-51; discussion 551.

22. Glineur D, D'hoore W, Price J, Dorméus S, de Kerchove L, Dion R, et al. Survival benefit of multiple arterial grafting in a 25 -year single-institutional experience: the importance of the third arterial graft. Eur J Cardiothorac Surg. 2012;42: 284-90; discussion 290-1.

23. Puskas JD, Thourani VH, Kilgo P, Cooper W, Vassiliades T, Vega JD, et al. Offpump coronary artery bypass disproportionately benefits high-risk patients. Ann Thorac Surg. 2009;88:1142-7.

24. Tarakji KG, Sabik JF III, Bhudia SK, Batizy LH, Blackstone EH. Temporal onset, risk factors, and outcomes associated with stroke after coronary artery bypass grafting. JAMA. 2011;305:381-90.

25. Raza S, Sabik JF III, Masabni K, Ainkaran P, Lytle BW, Blackstone EH. Surgical revascularization techniques that minimize surgical risk and maximize late survival after coronary artery bypass grafting in patients with diabetes mellitus. $J$ Thorac Cardiovasc Surg. 2014;148:1257-64; discussion 64-6. 